\title{
Valsecitos criollos en el folclore urbano cordobés entre I970 y 1980
}

\author{
Silvina G. Argüello
}

[Facultad de Artes de la Universidad Nacional de Córdoba]

\begin{abstract}
Resumen
En este trabajo estudio la historia local de un género musical -el vals criollo- que tuvo una amplia circulación en la ciudad de Córdoba durante la primera mitad del siglo XX. En las décadas de 1960 y 1970, fue incorporado al repertorio de intérpretes cordobeses de folclore que lograron difundir masivamente algunas de sus canciones. Entre ellas se destacan los valses criollos cuyas letras se refieren, frecuentemente, a personajes y lugares de la capital cordobesa. En la primera parte de la investigación, parto de la hipótesis de que estos músicos (compositores e intérpretes) lograron una posición privilegiada en el campo del folclore y fueron difundidos masivamente en gran parte porque emplearon las estrategias de legitimación que constituyeron y consolidaron el paradigma clásico del folclore que describe Claudio Díaz en Variaciones sobre el ser nacional (2009). La segunda parte de la investigación está destinada a la caracterización de música y letra de los valsecitos cordobeses más representativos y difundidos de la ciudad.
\end{abstract}

\section{Summary}

In this essay I explore the history of a local musical genre -the creole waltz- widely known in the city of Córdoba during the first half of the twentieth century. During the 60's and 70's, the genre became part of the repertoire of folk musicians of Córdoba with songs that reached mass recognition. The most popular song type, the creole waltz, usually has lyrics that depict landmark city sites and typical characters of Córdoba's capital city. In the first part of my research I intend to demonstrate that these performers and songwriters reached a highly privileged position in their field and received mass recognition largely by their use of the strategies of legitimation (that are described by Claudio Diaz in his essay Variaciones sobre el ser nacional, 2009), that shaped and consolidated the classic paradigm of folk music. The second part aims to characterize the lyrics and music of the most representative and widespread "valsecitos" (little waltzes) of the city of Córdoba. 